DOI: https://doi.org/10.34883/PI.2021.9.4.001

UDC 616-053.32-008.9-07:577.2

Nechytailo Yu., Godovanets O.

Bukovinian State Medical University, Chernivtsi, Ukraine

Нечитайло Ю.Н., Годованец А.С.

Буковинский государственный медицинский университет, Черновцы, Украина

\title{
Clinical and Molecular Mechanisms of Labor Oxidative Stress in Premature Infants
}

\author{
Клинико-молекулярные механизмы родового оксидативного \\ стресса у недоношенных детей
}

Abstract

Introduction. Conditions of labor oxidative stress (OS) at birth are accompanied by complex metabolic changes in the infant's body. The balance of the body's free radical oxidation (FRO) system and antioxidant defense system (AODS) is an important condition for adaptation during the transition from intrauterine to extrauterine life. An important factor in postnatal adaptation disorders is insufficient oxygen consumption, so the negative impact of hypoxia is considered as a general dysmetabolic distress syndrome, which results in the development of pathological conditions in the early neonatal period, formation of disorders of physical, neuropsychic development, and formation of somatic pathology in subsequent years of life. To reduce the frequency and severity of complications caused by antenatal hypoxia, it is topical to develop and implement the methods for early diagnosis of imbalance of the free radical oxidation system (FRO) and the antioxidant defense system (AODS) of the body in practice of neonatology. A violation of the ratio of their indicators leads to deterioration of mitochondrial oxidation, as well as to changes in the structure and function of cell membranes. Molecular rearrangement of cell membranes can be both an effective regulatory mechanism for adaptation of the infant's body and an element of damage in severe hypoxia under conditions of morpho-functional immaturity at birth.

Purpose. To study the features of the functioning of the FRO and AODS links of the body in premature newborns with severe perinatal pathology based on comprehensive diagnosis and analysis of its components.

Materials and methods. A comparative assessment of the indicators of FRO and AODS of the body in premature newborns of two observation groups was carried out, among which group I (experimental) included 38 infants born with gestational age of 32-34 weeks, who had clinical manifestations of severe perinatal pathology; group II included 27 conditionally healthy premature infants with gestational age at birth from 35 to 37 weeks, the indicators of additional examination methods of which served as controls for comparing the results of newborns of the main experimental group. The exclusion criteria were: gestational age at birth - 37 weeks or more, body weight more than $2500 \mathrm{~g}$, the presence of signs of intrauterine infection and congenital malformations. The features of adaptation of infants after birth and pathological conditions of the early neonatal period were analyzed, taking into account the leading symptoms of diseases. Additional methods of examination of newborns included a complex of indicators of FRO and AODS, namely: the level of Malone aldehyde (MA) and protein oxidative modification (POM) in blood plasma, ceruloplasmin (CP) level, catalase (CT) activity, content of HS groups of red blood cells and blood plasma, activity of glutathione peroxidase (GPx), glutathione-S-transferase (GST), glucose-6-phosphate 
dehydrogenase (G6PDH), and glutathione reductase (GR). The examination of infants was carried out in compliance with the basic provisions of human rights and biomedicine. Statistical processing of the obtained data was carried out using the licensed Statistica programs (StatSoft Inc., Version 7), Microsoft Excell (AtteStat, Version 12.5), and MedCalc Software (Version 16.1).

Results. The obtained data showed significant differences in adaptation at birth and the development of severe perinatal pathology in premature infants of the observation group, which was accompanied by imbalance of FRO and AODS indicators of the body. Clinical forms of pathology in newborns of the main group were represented by hypoxic-ischemic damage to the central nervous system, haemorrhages and signs of neonatal encephalopathy. The main syndromes were: cerebral depression syndrome, less often - cerebral excitability syndrome, autonomic dysfunction syndrome and convulsive syndrome. The course of diseases in infants was accompanied by stupor or coma, no or reduced response to examination, lack of or weak crying, distal flexion or atony. There was no or significant weakening of the sucking reflex, Moro and Robinson reflexes, decreased or no photoreaction, vertical nystagmus, tremor of the chin and limbs. Severe hemodynamic, respiratory, and gastrointestinal disorders were diagnosed. The imbalance of FRO and AODS indicators of the body in conditions of hypoxia was characterized by a significant increase of the level of MA, POM, probable differences, compared with the control group, in the indicators of CP, CT, HS-groups of blood plasma, the activity of GPx, GST, G6PD and GR.

\section{Conclusions:}

1. Insufficiency of AODS links with increased FRO activity causes increased sensitivity of premature newborns to hypoxia, reducing the reserve ability to adapt to the conditions of labor OS.

2. The development of severe forms of perinatal pathology in preterm birth is characterized by the increased level of MA and POM, the decrease of $C P, C T$, the level of HS groups of blood plasma, insufficient enzymatic activity of GPx, GST, G6PDH and GR.

Keywords: newborn, premature infant, adaptation, labor oxidative stress, hypoxia, protein oxidative modification, antioxidant defense system.

\section{Резюме}

Введение. Переход от внутриутробного к внеутробному существованию в условиях родового оксидативного стресса сопровождается сложными метаболическими изменениями в организме новорожденных детей, в том числе активацией прооксидантных и антиоксидантных механизмов. Дефицит кислорода является важным фактором нарушения функционирования и повреждения клеток и тканей, поэтому гипоксию рассматривают как общий энергетический дистресс-синдром, в результате которого возникают нарушения физического и нервно-психического развития детей, развивается патология, которая приводит к снижению качества жизни вследствие резидуальной неврогенной, психической, соматической и опорно-двигательной недостаточности. Для снижения частоты и тяжести осложнений, вызванных антенатальной гипоксией, актуальной является разработка и внедрение в практику неонатологии методов ранней диагностики дисбаланса системы свободнорадикального окисления (СРО) и антиоксидантной системы защиты (АОСЗ) организма, нарушение соотношения показателей которых вызывает изменения молекулярной организации и функции биологических мембран. Структурная перестройка клеточных мембран может быть как эффективным механизмом регуляции при адаптации организма, так и элементом повреждения в условиях стрессовой ситуации. Цель. Изучить особенности показателей СРО и системы АОСЗ в организме недоношенных новорожденных при перинатальной патологии тяжелой степени на основе комплексного исследования некоторых ее компонентов.

Материалы и методы. Проведена сравнительная оценка показателей СРО и АОСЗ у недоношенных новорожденных 2 групп наблюдения, среди которых группу исследования составили 38 детей, рожденных при сроке гестации 32-34 недели, имеющих клинические проявления 
перинатальной патологии тяжелой степени; группу сравнения составили 27 условно здоровых недоношенных детей, гестационный возраст которых при рождении составлял от 35 до 37 недель. Критериями исключения были: гестационный возраст ребенка 37 полных недель и более, масса тела более 2500 г, наличие признаков внутриутробной инфекции и врожденных пороков развития. Были проанализированы особенности адаптации детей при рождении и патологические состояния раннего неонатального периода с учетом ведущей симптоматики заболеваний. Дополнительные методы исследования включали комплекс показателей СРО и АОСЗ, а именно содержание ОМБ в плазме крови, уровень церулоплазмина (ЦП), активность каталазы (КТ), содержание HS-групп эритроцитов и плазмы крови, активность глюкозо-6фосфатдегидрогеназы (ГбФДГ), глютатионпероксидазы (ГП) и глютатионредуктазы (ГР). О6следование детей осуществлялось с соблюдением основных положений о правах человека и биомедицине. Статистическая обработка полученных данных проведена с использованием лицензированных программ Statistica (StatSoft Inc., Version 7), Microsoft Excell (AtteStat, Version 12.5) и MedCalc Software (Version 16.1).

Результаты. Полученные данные показали существенные различия адаптации при рождении и развитие тяжелой перинатальной патологии у недоношенных детей, состояние которых сопровождалось дисбалансом показателей СРО и АОСЗ организма. Клинические формы патологии представлены: гипоксически-ишемическим поражением центральной нервной системы (ЦНС) $(42,1 \%)$, кровоизлияниями (10,5\%), неонатальной энцефалопатией $(47,4 \%) ;$ у 25 новорожденных $(65,6 \%)$ наблюдался синдром церебрального угнетения, у 6 детей $(15,8 \%)$ - синдром церебральной возбудимости, у 5 детей $(13,2 \%)$ - синдром вегетативных дисфункций, у 4 детей (10,5\%) - судорожный синдром. Клиническое течение заболеваний у новорожденных основной группы наблюдения сопровождалось тяжелыми неврологическими расстройствами, в частности ступором (36,8\%) или комой $(26,3 \%)$, отсутствием $(47,4 \%)$ или пониженной реакцией на осмотр (76,3\%); отсутствием $(31,6 \%)$ или слабым криком $(65,8 \%) ;$ значительно выраженной дистальной флексией $(94,7 \%)$ или атонией $(18,4 \%)$. Отмечались отсутствие $(63,2 \%)$ или значительное ослабление сосательного рефлекса (36,8\%), рефлексов Моро $(44,7 \%)$ и Робинсона $(52,6 \%)$, снижение $(26,3 \%)$ или отсутствие фотореакции $(10,5 \%)$, вертикальный нистагм $(31,6 \%)$, а также тремор подбородка и конечностей $(44,7 \%)$. Отмечались выраженные гемодинамические $(68,4 \%)$, дыхательные $(97,4 \%)$ и гастроинтестинальные $(73,7 \%)$ расстройства. О6щая оценка неврологического статуса детей данной группы на третьи сутки жизни составила

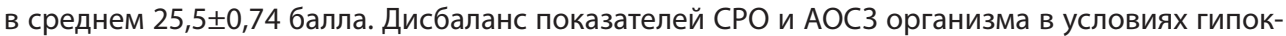
сии при преждевременном рождении характеризовался значительным повышением уровня ОМБ, достоверным снижением, по сравнению с контрольной группой, показателей ЦП, КТ, HS-групп плазмы крови, активности ГбФДГ, ГП и ГР. Изучение корреляционной зависимости между показателями системы СРО и АОСЗ в группах наблюдения показало увеличение уровня и появление новых, в отличие от контрольной группы, связей в группе недоношенных детей, имевших тяжелые формы перинатальной патологии.

Выводы. Дисбаланс звеньев АОСЗ при повышенной активности СРО обусловливает повышенную чувствительность организма недоношенных детей к гипоксии, уменьшая резервные возможности физиологической адаптации организма к условиям родового ОС, сопровождается развитием клинических проявлений дезадаптации, и в наиболее сложных случаях - тяжелых форм перинатальной патологии.

Ключевые слова: новорожденный, недоношенный ребенок, адаптация, родовой оксидативный стресс, гипоксия, окислительная модификация белков, система антиоксидантной защиты. 


\section{- INTRODUCTION}

During the transition from intrauterine to extrauterine existence under conditions of labour oxidative stress (OS), complex metabolic changes occur in the body of newborns, in particular, activation of the free radical oxidation (FRO) system and links of the antioxidant defence system (AODS) $[1,2]$. Within a few minutes after birth, the partial pressure of oxygen $\left(\mathrm{PaO}_{2}\right)$ under physiological conditions increases from $3.3 \mathrm{kPa}(25-35 \mathrm{~mm} \mathrm{Hg})$ up to $10.5 \mathrm{kPa}(80-90 \mathrm{~mm} \mathrm{Hg})$. This process usually occurs in full-term infants in about 5 minutes, in premature ones - in 7-8 minutes, which contributes to the formation of independent breathing and the restructuring of blood circulation. Physiologically, oxygen plays a key role in the energy supply of cells and the synthesis of adenosine triphosphate (ATP) during oxidative phosphorylation processes. Oxygen deficiency is an important factor in impaired functioning and damage to cells and tissues, so hypoxia is considered to be a general energy distress syndrome [3, 4]. Pathogenesis of hypoxia is diverse, characterized by complex dynamics, a wide range of multi-organ and functional-metabolic disorders at the molecular, cellular, organ and systemic levels. Numerous research data indicate the development of residual neurogenic, mental, somatic and musculoskeletal insufficiency in infants due to hypoxic damage to the body in the perinatal period in subsequent years of life [5].

The balance of the interaction of pro-oxidant and antioxidant mechanisms in the body of a newborn to a certain extent determines the nature of adaptation to the conditions of extrauterine life. Modern data from clinical and molecular studies indicate that OS, along with the mechanisms of excitotoxicity and inflammation, is one of the leading mechanisms of hypoxic damage to the body, which leads to the formation of functional and chronic pathology in subsequent years of life [10]. Insufficient activity of AODS components plays a significant role in the formation of clinical adaptation problems in premature infants in the early neonatal period. There fore it is advisable to conduct studies to identify the critical level of indicators that accompany the development of severe clinical manifestations of perinatal pathology in conditions of morphofunctional immaturity at premature birth.

To reduce the frequency and severity of complications caused by hypoxia, it is relevant to develop and implement the methods for early diagnosis of imbalance of FRO and AODS of the body in the practice of neonatology, since a violation of the ratio of their indicators causes changes in the molecular organization and function of biological membranes and insufficient mitochondrial oxidation. Structural rearrangement of cell membranes can be both an effective link in the regulation of adaptive processes, and an element of damage during hypoxia in a stressful situation $[6,7]$. The mechanism of AODS is one of the main links of the general adaptation syndrome, which contributes to the constancy of homeostasis of the body under conditions of labour stress, which can be both a physiological phenomenon and cause severe forms of perinatal pathology at premature birth [8,9]. Aspects of the influence of OS on the formation of short- and long-term adaptation of the body under conditions of hypoxia in prematurely born infants remain insufficiently studied. 


\section{- PURPOSE OF THE STUDY}

To study the features of the functioning of the FRO and AODS links of the body in premature newborns with severe perinatal pathology based on a comprehensive diagnosis and analysis of its components.

\section{- MATERIALS AND METHODS}

To reach the aim, two observation groups were formed. The first group (experimental) included 38 infants born at a gestational age of 3234 weeks, who were diagnosed with severe perinatal pathology; the second group (comparison group) included 27 conditionally healthy premature babies, whose gestational age was from 35 to 37 weeks, the results of an additional examination served as control ones for comparing data in newborns of the experimental group. The exclusion criteria were: infants with the gestational age of 37 weeks or more, body weight - more than $2500 \mathrm{~g}$, the presence of signs of intrauterine infection and congenital malformations.

The average body weight at birth in infants of group I was $1821.1 \pm 51.85 \mathrm{~g}$, body length $-42.2 \pm 0.33 \mathrm{~cm}$, head circumference $-29.7 \pm 0.26 \mathrm{~cm}$, chest circumference $-27.6 \pm 0.24 \mathrm{~cm}$. The average body weight at birth in infants of group II was $2251.5 \pm 34.14 \mathrm{~g}$, body length $-43.7 \pm 0.08 \mathrm{~cm}$, head circumference $29.8 \pm 0.20 \mathrm{~cm}$, chest circumference $-27.6 \pm 0.20 \mathrm{~cm}$. Studies of the correspondence between the indicators of morpho-functional maturity of infants and gestational age at birth were conducted using the Ballard scale and percentile tables. To assess adaptation disorders and the general condition of infants, the method of clinical examination of newborns was used, taking into account the Apgar score at 1 and 5 minutes of life. Clinical monitoring of infants in the neonatal period was carried out following the current recommendations of international and national protocols. The list of diseases of the early neonatal period included the determination of clinical diagnoses according to the ICD10 revision. In the course of the work, the nature of somatic and obstetric pathology in mothers of the observation groups, as well as the features of the course of pregnancy and labour were studied.

Methods of research of FRO indicators used in the work included: determination of the level of Malone aldehyde (MA) in red blood cells, which is the final product of lipid peroxidation (LPO) by reaction with thiobarbituric acid according to I.F. Meshchishen's method [11] and the indicator of protein oxidative modification (POM) in blood plasma - by reaction with 2,4-Dinitrophenylhydrazine with the formation of hydrazones of the characteristic absorption spectrum [12]. Studies of indicators of AODS of the newborns provided for: the level of ceruloplasmin (CP) by V.G. Kolb's et al. method [13]; catalase activity (CT) using ammonium molybdate by M.A. Koroliuk's et al. method [14]; content of HS-groups of red blood cells and blood plasma by I.F. Meshchishen's et al. method [15]; glutathione peroxidase (GP) activity - by the amount of oxidized glutathione formed from reduced hydrogen peroxide during neutralization in the glutathioperoxidase reaction [16]; glutathione-S-transferase (GST) activity - by spectrophotometric determination of the amount of reduced glutathione conjugate with 1-chloro-2,4-dinitrochlorobenzene, which was formed during the reaction under the action of the enzyme [17]; the activity of glucose-6-phosphate dehydrogenase (G6PDH) - by Kornberg and Horecker's method in the modification of Zakhariin [18], and the activity of 
glutathione reductase (GR) - in blood hemolysates (1:20) with a decrease in the amount of NADPH [19]. Examination of newborns was carried out using micro procedures using small volumes of blood. Blood sampling was performed in an amount of $1.0 \mathrm{ml}$ from the umbilical vein, with the addition of $0.1 \mathrm{ml}(500$ units) of heparin diluted with $0.4 \mathrm{ml}$ of $0.9 \% \mathrm{NaCl}$ in a ratio of 1:4. By centrifugation of heparinized blood at $3000 \mathrm{vol} / \mathrm{min}$ plasma was separated, which was frozen in test tubes at $12^{\circ} \mathrm{C}$. The research was conducted during 2013-2015 based on specialized laboratories of Bukovinian State Medical University (Chernivtsi).

The examination of infants was carried out in compliance with the main provisions of Good Clinical Practice (1996), the Council of Europe Convention on Human Rights and Biomedicine (1997), the Helsinki Declaration of the World Medical Association on the Ethical Principles of conducting scientific medical research with human participation (1964-2008), Order of the Ministry of Healthcare of Ukraine No. 690 dated 23.09.2009 (amended by Order of the Ministry of Healthcare of Ukraine No. 523 dated 12.07.2012), and approved by the commission on biomedical ethics of Bukovinian State Medical University. Informed consent of the patients' parents was obtained to research after explaining the aim and objectives of the study.

Statistical processing of the obtained data was carried out using licensed Statistica programs (StatSoft Inc., Version 7), Microsoft Excell (AtteStat, Version 12.5), and MedCalc Software (Version 16.1). The procedures, logic and interpretation of the obtained analysis results were based on the main provisions of medical and biological statistics [20, 21]. For the normal distribution of quantities (Shapiro - Wilk test $>0.05$ ), parametric statistical methods were used to calculate the arithmetic mean (M) and the error of representativeness of the average value $(\mathrm{m})$. Comparison of quantitative indicators with the normal distribution was carried out using the t-criterion.

\section{- RESULTS AND DISCUSSION}

The results of assessing the condition of infants on the Apgar score in infants of group I showed severe violations of acute neonatal adaptation at birth. In particular, the score of newborns at the $1^{\text {st }}$ minute was $4.8 \pm 0.20$, at the $5^{\text {th }} \min -6.0 \pm 0.06$. At the same time, 27 infants $(71.1 \%)$ were born with an Apgar score of 4-6 at the $1^{\text {st }}$ minute of life, 8 infants (21.1\%) were born with an Apgar score of $0-3$ at the $1^{\text {st }}$ minute of life. It should be noted that 9 infants in this group (23.7\%) were born with a satisfactory Apgar score at the 1st minute of their life, but during the first 2 days, their condition significantly worsened.

In the first week of life, all infants of group I had signs of respiratory distress. Downes score 1-3 was noted in 10 cases (26.3\%), 4-7 - in 22 cases (57.9\%), more than 7 - in 6 cases (15.8\%). Manifestations of neonatal jaundice were detected in 17 infants (44.7\%) of this group, 4 infants (10.5\%) had complications with the development of post-resuscitation pneumonia.

Secondary to morpho-functional immaturity, clinical signs of hypoxic damage to the central nervous system were found in all newborns of the main group. In particular, 16 infants $(42.1 \%)$ had hypoxic-ischemic lesions, 4 infants (10.5\%) had haemorrhages, and 18 infants were diagnosed with neonatal encephalopathy (47.4\%). At the same time, 25 newborns (65.6\%) had cerebral depression syndrome, 6 infants $(15.8 \%)$ had cerebral excitability 
syndrome, 5 infants (13.2\%) had autonomic dysfunction syndrome, and 4 infants (10.5\%) had the convulsive syndrome. The clinical course of diseases in newborns of this group was characterized by such neurological disorders as stupor - in 14 cases (36.8\%) or coma - in 10 cases (26.3\%); absence in 18 newborns (47.4\%) or reduced response to examination in 20 newborns (52.6\%); absence of shouting - in 15 newborns (39.5\%) or weak cry - in 23 newborns (60,5\%); significantly pronounced distal flexion in 36 newborns $(94.7 \%)$ or atony - in 2 newborns (5.3\%). There was no sucking reflex in 24 cases $(63.2 \%)$ or a significant weakening of it in 14 cases (36.8\%); lack of Moreau reflex - in 17 cases (44.7\%) and Robinson reflex - in 20 cases (52.6\%); decrease of photoreaction - in 10 infants $(26.3 \%)$ or absence of it - in 4 infants (10.5\%); vertical nystagmus was identified in 12 newborns (31.6\%), large-scale tremor of the chin and limbs in 17 infants (44.7\%). Severe manifestations of hemodynamic disorders were observed in 26 cases (68.4\%), respiratory disorders - in 37 cases (97.4\%) and gastrointestinal disorders - in 28 cases (73.7\%).

Indicators of early neonatal adaptation after birth in infants of group II were satisfactory. The average Apgar score at the $1^{\text {st }}$ minute of life was $6.7 \pm 0.08$, and at the $5^{\text {th }}$ minute $-7.1 \pm 0.09$. Newborns in this group showed no signs of clinical dysadaptation after birth and during the early neonatal period. The infants were in the rooming-in and were exclusively breastfed.

Modern data from clinical and molecular studies show that the intensity of OS is one of the pathological links in the formation of severe forms of dysadaptation in the early neonatal period, causing the development of functional and chronic pathology in subsequent years of life. The full functioning of antioxidant defence mechanisms prevents damage to cellular structures during the formation of active oxygen molecules (AOMs) during electron transport in the mitochondrial respiratory chain. Violation of the ratio of prooxidants to antioxidants leads to the intensification of free radical and peroxide reactions with the accumulation of products that damage mitochondrial membranes. In turn, this causes pathological changes in the structure and function of cell membranes of organ systems, which causes severe forms of clinical dysadaptation in newborns when the harmful effects of antenatal and perinatal risk factors are implemented $[5,7,9]$.

The synthesis of antioxidant defence enzymes, as well as the regulatory response, can vary both quantitatively and qualitatively, depending on the activity of oxidative action and the individual response of the body, which in particular depends on the morphofunctional maturity of the infant at birth. The antioxidant potential of the fetus is significantly lower than that of older infants and adults. In particular, there is a decrease in the activity of enzymes - inactivators of free radicals and many other components of AODS. Studies show that the activity of AODS enzymes such as GPx, catalase $C T$, and SOD tends to increase with an increase in the gestational age of a newborn $[1,2,6,8]$.

Studies of the indicators of FRO and AODS of the newborns of the experimental group I showed significant differences relative to the indicators of group II. In particular, the severe condition in infants of this group was accompanied by a significant increase in MA levels - 34.0 1.70 and $15.3 \pm 0.77 \mu \mathrm{mol} / /$ respectively $(p<0.05)$. The POM indicator in newborns of group I was $105.2 \pm 3.85 \mathrm{E} / \mathrm{g}$ of protein, while the norm in infants of group 
II (control) was $63.4 \pm 1.48 \mathrm{E} / \mathrm{g}, \mathrm{p}<0.05$. At the same time, a probable inverse correlation was established between the level of MA $(r=-0.78, p<0.05)$ and the intensity of POM and the gestational age of the child $(r=-0.62, p<0.05)$. This, in our opinion, confirms the fact that at premature birth there is a more pronounced intensification of the processes of LPO and POM, accompanied by more significant violations of protein functions in the infant's body. According to the references, the POM index is an integral part of many factors that control the synthesis and oxidation of proteins, on the one hand, and the activity of various proteases, on the other. Metal-catalyzed oxidation is crucial in the mechanisms of free radical damage in the body. Any system that forms hydrogen peroxide and reduces $\mathrm{Fe}^{3+}$ to $\mathrm{Fe}^{2+}$ or $\mathrm{Cu}^{2+}$ to $\mathrm{Cu}^{+}$can cause selective modification of proteins that have a metal-binding site. Processes that affect cellular levels of $\mathrm{H}_{2} \mathrm{O}_{2}, \mathrm{Fe}^{3+}$ and $\mathrm{Cu}^{2+}$ can also be crucial factors in metabolic disorders. Thus, the significant activity of FRO links in the body of newborns at premature birth causes a high risk of destabilization of the phospholipid layer of cell membranes under hypoxia conditions during the implementation of perinatal risk factors $[6,7,22]$.

According to our data, the activation of FRO processes in newborns of group I was accompanied by a certain insufficiency of AODS links. The obtained indicators in infants of observation groups are presented in the table.

Comparative analysis of the CP content in the observation groups showed that infants of group I had a significant decrease in the indicator, compared with group II $-26.7 \pm 1.5$ and $61.8 \pm 2.87 \mathrm{E} / \mathrm{g}$ of protein $(p<0.05)$, respectively, which indicates insufficient reserve function of this enzyme during premature birth in seriously ill newborns. According to the research data, CP is a universal extracellular "neutralizer" of free radicals (FR). It has superoxide dismutase activity: it restores superoxide radicals in the blood to oxygen and water protecting against damage to the lipid structures of membranes. It can oxidize various substrates, including serotonin, catecholamines, polyamines, and polyphenols; convert $\mathrm{Fe}^{2+}$ to $\mathrm{Fe}^{3+}$. $\mathrm{CP}$ acts as a universal extracellular trap of $\mathrm{FR}$ and is one of the factors of neuroendocrine regulation and natural defence of the body under hypoxic stress $[22,23]$.

\section{Features of AODS indicators in premature infants with perinatal pathology in comparison with the control group $(\mathrm{M} \pm \mathrm{m})$}

\begin{tabular}{|l|l|l|}
\hline Indicators & $\begin{array}{l}\text { Group II } \\
\text { (control group), } \mathbf{n = 2 7}\end{array}$ & $\begin{array}{l}\text { Group I } \\
\text { (study group), } \mathbf{n = 3 8}\end{array}$ \\
\hline Plasma ceruloplasmin, E/g of protein & $61.8 \pm 2.87$ & $26.7 \pm 1.5^{*}$ \\
\hline Plasma catalase, E/min $\times$ g of protein & $5.0 \pm 0.22$ & $1.0 \pm 0.12^{*}$ \\
\hline $\begin{array}{l}\text { HS-groups of red blood cells, } \mu \mathrm{mol} / \mathrm{ml} \text { of red blood } \\
\text { cell mass }\end{array}$ & $1.0 \pm 0.04$ & $0.8 \pm 0.04$ \\
\hline HS-groups of blood plasma, $\mu \mathrm{mol} / \mathrm{g}$ of protein & $1.4 \pm 0.06$ & $0.8 \pm 0.06^{*}$ \\
\hline Erythrocyte G6PDH, $\mu \mathrm{mol} / \mathrm{min} \times \mathrm{HGB}$ & $96.2 \pm 4.81$ & $83.7 \pm 4.19^{*}$ \\
\hline GPx of red blood cells, $\mu \mathrm{mol} / \mathrm{min} \times \mathrm{HGB}$ & $5.3 \pm 0.27$ & $4.0 \pm 0.10^{*}$ \\
\hline GR of red blood cells, $\mu \mathrm{mol} / \mathrm{min} \times \mathrm{HGB}$ & $6.3 \pm 0.32$ & $5.1 \pm 0.26^{*}$ \\
\hline Plasma ceruloplasmin, E/g of protein & $3.6 \pm 0.18$ & $3.6 \pm 0.19$ \\
\hline
\end{tabular}

Note: * possible differences compared to the control, $\mathrm{p}<0.05$. 
The activity of CT in the blood serum of newborns of group I also had a significant difference compared to the control group and was $1.0 \pm 0.12$ and $5.0 \pm 0.22 \mathrm{E} / \mathrm{min} \times \mathrm{g}$ of protein respectively $(\mathrm{p}<0.05)$. According to the references, $\mathrm{CT}$ is an enzyme involved in the neutralization of the non-radical active oxygen form $\mathrm{H}_{2} \mathrm{O}_{2}$, a gem-containing enzyme localized mainly in cell peroxisomes. The large molecular weight of the enzyme prevents its passage through the cell membrane. In the oxidized state, CT can act as a peroxidase, catalyzing the oxidation of alcohols or aldehydes, and also act as a source of active oxygen molecules (AOM) formation itself $[6,10,22]$.

An important defence system of the body from FRO products is the system of glutathione and glutathione-dependent enzymes. Having two forms - reduced and oxidized, glutathione is the most important redox system that protects the body from the toxic effects of peroxides, in particular hydrogen peroxide. Data from experimental studies indicate a state of glutathione deficiency under stressful conditions, which occurs with the intensification of LPO and oxidation of protein HS groups [23], which is confirmed by clinical data of our study. Analysis of the obtained data showed a certain tendency to decrease the level of HS groups of red blood cells $0.8 \pm 0.04$ and $1.0 \pm 0.04 \mu \mathrm{mol} / \mathrm{ml}$ of red blood cell mass in groups I and II respectively ( $p>0.05)$ and a likely decrease in the level of HS-groups in blood plasma $-0.8 \pm 0.06$ and $1.4 \pm 0.06 \mu \mathrm{mol} / \mathrm{g}$ of protein $(p<0.05$ ). Insufficient content of HS groups in blood plasma in severe neonatal conditions indicates a decrease in the activity of the glutathione system, which is associated with both insufficient production of reduced glutathione and an increase in its breakdown for FR inactivation. According to the references, the main component of HS groups in blood plasma is HS groups of proteins [2, 6, 23].

Glutathione enzymes GPx and GST are involved in the body's protective functions against the toxic effects of various peroxides, including hydrogen peroxide, in case of hypoxia. The main part of GPx is localized in the cytosol, the other - in the mitochondria. With a decrease in the level of GPx, the body's resistance to oxidative damage decreases, which leads to the development of free radical pathology. Studies have shown that GPx activity is significantly reduced in infants of group I compared to group II $-83.7 \pm 4.19$ and $96.2 \pm 4.81 \mu \mathrm{mol} / \mathrm{min} \times \mathrm{HB}$ respectively $(p<0.05)$. Selenium-containing GPx is involved in the neutralization of peroxynitrite. The affinity of GPx for $\mathrm{H}_{2} \mathrm{O}_{2}$ is higher than that of $\mathrm{CT}$, so it works better at low concentrations of hydrogen peroxide while protecting cells from OS caused by very high concentrations of $\mathrm{H}_{2} \mathrm{O}_{2}$, a key function that belongs to $\mathrm{CT}$. Noting the functional role of GPx in protecting the body from OS, the enzyme is considered one of the most important components of AODS [5, 22]. The activity of the GST enzyme in the blood plasma of newborns of the main group was also significantly reduced, compared with the activity of the indicator in the comparison group, and, respectively, was $4.0 \pm 0.10$ and $5.3 \pm 0.27 \mu \mathrm{mol} / \mathrm{min} \times \mathrm{mg}$ of protein $(p<0.05)$. GST is an enzyme located mainly in the cytosol of cells. The main function of GST is to protect cells from LPO products by reducing them, attaching a glutathione molecule to the substrate, or nucleophilic substitution of hydrophobic groups. Thus, this enzyme is a fundamentally important component of AODS, especially in protecting against endogenous metabolites that are formed as a result of OS $[23,24]$. 
Glutathione reduction, according to the references, occurs by oxidation of glucose-6-phosphate and 6-phosphogluconate in the pentosephosphate cycle, which in turn ensures the formation of NADPH $[25,26]$. G6PD and GR are involved in the regeneration of glutathione from the oxidized form to the reduced one. We found a significant decrease in the activity of G6PD at preterm birth in infants of group I compared to group II $5.1 \pm 0.26$ and $6.3 \pm 0.32 \mu \mathrm{mol} / \mathrm{min} \times \mathrm{HB}(\mathrm{p}<0.05)$, respectively, the activity of GR of red blood cells in severe neonatal conditions did not significantly differ from the control group $-3.6 \pm 0.19$ and $3.6 \pm 0.18 \mu \mathrm{mol} / \mathrm{min} \times \mathrm{HB}(\mathrm{p}>0.05)$. In our opinion, the data obtained indicate the insufficiency of reparative biosynthesis processes, including the mechanisms of the glutathione system and glutathione-dependent enzymes in the body of premature newborns with severe forms of perinatal pathology.

Thus, the results of clinical and laboratory studies of the FRO and AODS systems in premature newborns showed significant changes in indicators that confirm the results of modern experimental studies on the importance of the role of this pathogenetic link in the formation of dysadaptation syndromes and severe perinatal pathology. The study of the possibilities of pharmacological correction of AODS indicators with increased FRO activity in conditions of birth OS and hypoxia secondary to morpho-functional immaturity in premature infants will develop approaches to the treatment of severe forms of perinatal pathology to improve adaptation opportunities in the early neonatal period and prevent the development of long-term consequences of pathology in subsequent years of life.

\section{- CONCLUSIONS}

1. Insufficiency of AODS links with increased FRO activity causes increased sensitivity of premature newborns to hypoxia, reducing the reserve ability to adapt to the conditions of labour OS.

2. The development of severe forms of perinatal pathology at preterm birth is characterized by an increased level of MA and POM, a decrease in $\mathrm{CP}, \mathrm{CT}$, the level of HS groups of blood plasma, the insufficient enzymatic activity of GPx, GST, G6PDH and GR.

\section{Prospects for further research}

Studying the clinical and molecular aspects of the development of «free radical disease» in premature newborns and finding means of metabolic correction to activate regulatory mechanisms and links of the body's antioxidant defence.

Conflict of interest. The authors declare no conflict of interest.

\section{- REFERENCES}

1. Disdier C, Stonestreet BS. (2020) Hypoxic-ischemic-related cerebrovascular changes and potential therapeutic strategies in the neonatal brain. J Neurosci Res, vol. Jul, no 98(7), pp. 1468-1484. doi: 10.1002/jnr.24590. Epub 2020 Feb 14. PMID: 32060970; PMCID: PMC7242133.

2. Koehn LM, Chen X, Logsdon AF, Lim YP, Stonestreet BS. (2020) Novel Neuroprotective Agents to Treat Neonatal Hypoxic-Ischemic Encephalopathy: Inter-Alpha Inhibitor Proteins. Int. J Mol Sci, vol. Dec 2, no 21(23), pp. 91-93. doi: 10.3390/ijms21239193. PMID: 33276548; PMCID: PMC7731124.

3. Disdier C, Stonestreet BS. (2020) Hypoxic-ischemic-related cerebrovascular changes and potential therapeutic strategies in the neonatal brain. $J$ Neurosci Res, vol. Jul, no 98(7), pp. 1468-1484. doi: 10.1002/jnr.24590. Epub 2020 Feb 14. PMID: 32060970; PMCID: PMC7242133. 
4. Tipple TE, Ambalavanan N. (2019) Oxygen Toxicity in the Neonate: Thinking Beyond the Balance. Clin Perinatol, vol. Sep, no 46(3), pp. $435-447$. doi: 10.1016/j.clp.2019.05.001. Epub 2019 Jun 8. PMID: 31345539; PMCID: PMC6662609.

5. Edwards AB, Anderton RS, Knuckey NW, Meloni BP. (2018) Perinatal Hypoxic-Ischemic Encephalopathy and Neuroprotective Peptide Therapies: A Case for Cationic Arginine-Rich Peptides (CARPs). Brain Sci, vol. Aug 7, no 8(8), p. 147. doi: 10.3390/brainsci8080147. PMID: 30087289; PMCID: PMC6119922.

6. Perez M, Robbins ME, Revhaug C, Saugstad OD. (2019) Oxygen radical disease in the newborn, revisited: Oxidative stress and disease in the newborn period. Free Radic Biol Med, vol. Oct, no 142, pp. 61-72. doi: 10.1016/j.freeradbiomed.2019.03.035. Epub 2019 Apr 5. PMID: 30954546; PMCID: PMC6791125.

7. Perrone S, Laschi E, Buonocore G. (2019) Biomarkers of oxidative stress in the fetus and in the newborn. Free Radic Biol Med, vol. Oct, no 142, pp. 23-31. doi: 10.1016/j.freeradbiomed.2019.03.034. Epub 2019 Apr 5. PMID: 30954545.

8. Vento M. (2019) Oxidative stress in the perinatal period. Free Radic Biol Med, vol. Oct, no 142, pp. 1-2. doi: 10.1016/j.freeradbiomed.2019.07.028. Epub 2019 Jul 25. PMID: 31351951.

9. Lee JW, Davis JM. (2011) Future applications of antioxidants in premature infants. Curr Opin Pediatr, vol. Apr, no 23(2), pp. 161-6. doi: 10.1097/ MOP.0b013e3283423e51. PMID: 21150443; PMCID: PMC3289059.

10. Millar LJ, Shi L, Hoerder-Suabedissen A, Molnár Z. (2017) Neonatal Hypoxia Ischaemia: Mechanisms, Models, and Therapeutic Challenges. Front Cell Neurosc, vol. May 8, no 11, p. 78. doi: 10.3389/fncel.2017.00078. PMID: 28533743; PMCID: PMC5420571.

11. Meshhyshen I.F. (1998) Metod vyznachennya okyslyuval"noyi modyfikaciyi bilkiv plazmy (syrovatky krovi) [Method for determining oxidative modification of plasma proteins (blood serum)]. Bukovyns"kyj medychnyj visnyk, vol. 2, no 1, pp. 156-158.

12. Kolb V.H. Spravochnyk po klynycheskoj byoxymyy [Clinical Biochemistry Handbook]. Minsk, 1982, 311 p.

13. Korolyuk M.A. (1988) Metod opredelenyya aktyvnosty katalazi [Method for determination of catalase activity]. Laboratornoe delo, vol. 1, pp. 6-19.

14. Meshhyshen I.F., Hryhoriyeva N.P. (2002) Metod kil"kisnoho vyznachennya HS-hrup u krovi [The method of determining the HS-groups in blood]. Bukovyns"kyj medychnyj visnyk, vol.6, no 2, pp. 190-192.

15. Kornberg A., Horecker B.L. (1955) Glucoso-6-P-degydrogenase. Method in Enzymmol, vol. 1, pp. 329-350.

16. Herush I.V., Meshhyshen I.F. (1998) Stan hlutationovoyi systemy krovi za umov eksperymental "noho vyrazkovoho urazhennya hastroduodenal" noyi zony ta diyi nastojky exinaceyi purpurovoyi [The state of the glutathione blood system under the conditions of experimental ulcerative lesions of the gastroduodenal zone and the action of tincture of Echinacea purpurea]. Visnyk problem biolohiyi ta medycyny, vol. 7, pp. 10-15.

17. Vlasova SN, Shabunyna EY, Pereslehyna Ya. (1990) The activity of glutathione-dependent erythrocyte enzymes in chronic liver diseases in children. Lab. delo, vol. 8, pp. 19-21.

18. Fletcher R, Fletcher S, Vahner E. (1998) Klynycheskaya эрydemyolohyya. Osnovi dokazatel»noj medycyni [Clinical epidemiology. Basics of evidencebased medicine]. Moskva: Medya Sfera, $352 \mathrm{p}$.

19. Pokrovskyj VY, Bryko NY (2012) Obshhaya epydemyolohyya s osnovamy dokazatel"noj medycyni [General epidemiology with the basics of evidence-based medicine]. Rukovodstvo k praktycheskym zanyatyyam: ucheb. posob. 2-eyzd., yspr. y dopol [Guide to practical lessons: tutorial, $2^{\text {nd }}$ edition, revised and supplemented]. Moskva: GEOTAR-Medya, $496 \mathrm{p}$.

20. Wang Y, Wu Y, Li T, Wang X, Zhu C. (2019) Iron Metabolism and Brain Development in Premature Infants. Front Physiol, vol. Apr 25, no 10, p. 463. doi: 10.3389/fphys.2019.00463. PMID: 31105583; PMCID: PMC6494966.

21. Moore TA, Ahmad IM, Zimmerman MC. (2018) Oxidative Stress and Preterm Birth: An Integrative Review. Biol Res Nurs, vol. Oct; no 20(5), pp. 497-512. doi: 10.1177/1099800418791028. Epub 2018 Aug 1. PMID: 30068228; PMCID: PMC6346316.

22. Perrone S, Santacroce A, Longini M, Proietti F, Bazzini F, Buonocore G. (2018) The Free Radical Diseases of Prematurity: From Cellular Mechanisms to Bedside. Oxid Med Cell Longev, vol. Jul 24, pp. 7483062. doi: 10.1155/2018/7483062. PMID: 30140369; PMCID: PMC6081521.

23. Reid GK, Berardinelli AJ, Ray L, Jackson AR, Neish AS, Hansen JM, Denning PW. (2017) Timing of developmental reduction in epithelial glutathione redox potential is associated with increased epithelial proliferation in the immature murine intestine. Pediatr Res, vol. Aug, no 82(2), pp. 362-369. doi: 10.1038/pr.2017.49. Epub 2017 Jun 7. PMID: 28288146; PMCID: PMC5552438.

24. Quispe RL, Jaramillo ML, Galant LS, Engel D, Dafre AL, Teixeira da Rocha JB, Radi R, Farina M, de Bem AF. (2019) Diphenyl diselenide protects neuronal cells against oxidative stress and mitochondrial dysfunction: Involvement of the glutathione-dependent antioxidant system. Redox Biol, vol. Jan, no 20, pp. 118-129. doi: 10.1016/j.redox.2018.09.014. Epub 2018 Sep 25. PMID: 30308475; PMCID: PMC6176650.

Submitted/Подана: 01.03.2021

Accepted/Принята: 22.11.2021

Contacts/Контакты: godovanec.oleksij@bsmu.edu.ua, nechitailo.yuri@bsmu.edu.ua

The article is published in the author's edition. 